\title{
Acoustic Safety Management at the Locksmith's Workplace Mechanic-Repairman to Replace the Filter Material in the Technological Process of Obtaining of Apatite Concentrate
}

\author{
Ekaterina Chalovskaya ${ }^{1, *}$, Tatiana Kaverzneva ${ }^{1,2}$, Igor Skripnik ${ }^{3}$, Vladimir Senchenko ${ }^{4}$ and Ilya Klochihin ${ }^{1}$ \\ ${ }^{1}$ Peter the Great St.Petersburg Polytechnic University, Higher school of technosphere safety, RU-195251, Saint-Petersburg, Russian \\ Federation \\ ${ }^{2}$ St Petersburg Academic University, RU-194021, Saint-Petersburg, Russian Federation \\ ${ }^{3}$ Saint-Petersburg University of State Fire Service of Emercom of Russia, RU-196105, Saint-Petersburg, Russian Federation \\ ${ }^{4}$ Volgograd branch of Rostelecom PJSC, RU-400048, Volgograd, Russian Federation
}

\begin{abstract}
In this w ork, m easures ar e b eing d eveloped t o r educe the $n$ oise 1 evel at the w orkplace of a mechanic-repairman to $\mathrm{r}$ eplace filter $\mathrm{c}$ loth. $\mathrm{B}$ ased on $\mathrm{t}$ he $\mathrm{r}$ esults of production $\mathrm{c}$ ontrol a nd a thorough assessment of working conditions, the source of noise was determined to be the VDN-17 fan. The analysis of Russian and foreign studies in the field of the negative impact of noise on the human health and methods of dealing with in dustrial noise has been carried out. As a r esult, a technical method of reducing negative impact of noise was selected and the acoustic efficiency of the muffler for the VDN-17 fan was calculated.
\end{abstract}

\section{Introduction}

According to th e F ederal $\mathrm{S}$ tate $\mathrm{S}$ tatistics $\mathrm{S}$ ervice, th e percentage of workers employed in harmful and hazardous conditions to the total number of employees in 2018 decreased in relation to 2017 by $2 \%$ [1].

The F ederal S tate $\mathrm{S}$ tatistics Service d ata for 2018 showed that the most harmful a nd ha zardous a ctivities are: $\mathrm{m}$ ining - 54.7\% a nd manufacturing - 43.2\% [ 1 . Thus, workers e mployed i $\mathrm{n}$ t he mining i ndustry a re constantly exposed to harmful factors, o ne of the most dangerous is exposure to occupational noise, which leads to $\mathrm{d}$ iseases of $\mathrm{t}$ he car diovascular s ystem a nd hearing impairment. According to the results of the study [2], it was revealed th the mining industry $r$ anks first in the prevalence of $h$ earing $d$ iseases. $T$ his i s co nfirmed $b y$ many studies of scientists and the Federal state statistics service, a ccording $\mathrm{t}$ o da ta $\mathrm{f}$ or 2018 , $\mathrm{t}$ he w orking conditions of e mployees of the mining a nd processing industry ar e ch aracterized $b$ y $t$ he $p$ resence o f $h$ armful factors: chemistry $-10.1 \%$, noise $-35.9 \%$, as well as the severity of the labor process - 38,5\% [1], [3]. Analysis of the impact of harmful and dangerous factors shows that workers in the mining industry have an average and high risk of developing occupational diseases [4].

According to the data of the state mining supervision for $2018, t$ he $t$ otal $n$ umber of workers e mployed a $t$ hazardous $p$ roduction $f$ acilities in $t$ he mining i ndustry was 226 thousand people, and the volume of rock mass production i ncreased b y $5 \%$ compared to the p revious reporting pe riod, $r$ espectively, acci dents a nd i njuries to workers o ccur. A s c an b e s een from Appendix 3 , the number of injured workers is decreasing every year, but the number of accidents has been stable over the past 4 years. According to the report of the Federal Service for Environmental, T echnological a nd $\mathrm{N}$ uclear $\mathrm{S}$ upervision for 2018 , the number of de aths de creased by 1.6 times compared t o 2017 [ 5]. A study ba sed o n a ccident statistics o ver a te $n$-year pe riod found that $85 \%$ of a 11 injuries are associated with mining equipment, and $90 \%$ of $\mathrm{f}$ atalities with mobile e quipment, in cluding $\mathrm{h}$ and tools. Truck operators and repairmen are at the highest risk [6].

This research examines the workplace of a repairman for $r$ eplacing $f$ ilter $\mathrm{c}$ loth ( hereinafter $r$ eferred $t o$ as a repairman i $\mathrm{n}$ t he $\mathrm{P}$ olar $\mathrm{D}$ ivision). $\mathrm{T}$ his $\mathrm{p}$ rofession $\mathrm{i} \mathrm{n}$ various fields of $\mathrm{i}$ ndustry is o ften a ssociated with $\mathrm{t}$ he negative impact of the following factors: industrial noise, vibration, microclimate parameters, exposure to harmful substances, the severity and intensity of the labor process $[3,6,7]$. The constant exposure to occupational noise has a negative effect on the state of the nervous system, such as $i$ rritability, $h$ eadaches, $f$ atigue, $s$ leep $d$ isturbance, memory i mpairment a nd, acco rdingly, $t$ his 1 eads $t o$ occupational diseases [8].

The ai $\mathrm{m}$ o f $\mathrm{t}$ he s tudy i s t o d evelop m easures $\mathrm{t} o$ reduce the noise level at the workplace of the mechanicrepairman to $\mathrm{r}$ eplace $\mathrm{t}$ he filter $\mathrm{c}$ loth. $\mathrm{T}$ o $\mathrm{s}$ olve it, following main tasks:

1. A nalysis o f no ise a ffecting $t$ he mechanicrepairman;

2. Analysis of noise sources;

3. Development of measures to reduce noise exposure;

have been accomplished. 


\section{Methods}

\subsection{Noise reduction techniques}

When considering industrial noise as a biological factor, it was found that the noise affecting the employee's body leads to a decrease in performance.

Hearing loss f rom exposure to noise is the $\mathrm{s}$ econd most $\mathrm{c}$ ommon c ondition in the mining i ndustry. In the study [9], it is proposed to reduce the noise level from two rotating cutting drums by increasing the rigidity of the outer plates, which is the most practical and durable. This method was able to organize noise reduction by 3 $\mathrm{dB}$. The most e ffective is the fight a gainst $n$ oise a $t$ its source [10].

The a uthor in the a rticle argues $t$ hat $t$ he ef fect of increased noise e ntails a $\mathrm{n}$ i ncrease i $\mathrm{n}$ the co sts of an employee's e fforts to perform work. The use of various noise absorbers is proposed, including their designs. The results of the study [11] claim that every 5-10 years the increase in noise emission is about $5 \mathrm{dBA}$. According to the results of the analysis, diseases most often occurred in $\mathrm{p}$ ersons with a 1 ong work e xperience. $\mathrm{T}$ he a uthor proposes to us e n oise protection s tructures in or der to combat o ccupational diseases. We are talking ab out the development of noise-absorbing pa nels on the ba sis of the laboratory of the Department of Technosphere Safety of the Federal State Budgetary Educational Institution of Higher Professional Education IzhSTU named after M.T. Kalashnikov".

According $t$ ot he Ministry of $\mathrm{L}$ abor a nd S ocial Protection, sensorineural hearing loss is detected in 30$40 \%$ of al $1 \mathrm{r}$ ecorded occupational $\mathrm{d}$ iseases. T he ar ticle [12] $\mathrm{d}$ iscusses act ive headphones with $\mathrm{t}$ he ab ility $\mathrm{t} o$ adjust the sound volume, that is, to amplify quiet sounds and at the same time to make ex cessively loud sounds quieter, and they can also have built-in walkie-talkies for the convenience of employees' communication.

Thus, it i s possible to implement both te chnical and organizational measures to c ombat the n egative i mpact of $n$ oise. $T$ he $m$ ost ef fective $t$ echnical measure i s $t o$ tackle the source of the noise, but this is often a complex process. The $\mathrm{m}$ ost co mmon i s $\mathrm{t}$ he $\mathrm{u}$ se o f co llective means of p rotection, $\mathrm{s}$ uch a s in stalling $\mathrm{n}$ oise-absorbing panels, $t$ his i s al so a $v$ ery costly $p$ rocess. $T$ he most frequent a nd i nconvenient $f$ or $w$ orkers i s $t$ he us e of personal $\mathrm{p}$ rotective eq uipment, $\mathrm{s}$ uch a $\mathrm{s}$ h eadphones or ear plugs [13].

\subsection{Analysis of noise sources based on production control fata at the workplace of a mechanic-repairman to replace filter cloth}

In industrial shops, many machines and devices are used that ge nerate hi gh 1 evels of noise, w hich is the $\mathrm{m}$ ain cause of hearing loss.

At the workplace of a $r$ epairman, acco rding to the results of p roduction co ntrol, an i ncreased $n$ oise 1 evel was $r$ evealed a $t$ the marks of $d$ isk a nd $b$ elt vacuum filters. This is due to the fact that these control points are located near the noise source - the fans of the VDN-17 drying $d$ rums. $C$ entrifugal $b$ lowing fans of single i nlet type V D a re de signed to s upply air to the furnaces of steam $b$ oilers [ 14]. The o verall an d co nnecting dimensions o $\mathrm{ft}$ he $\mathrm{s}$ moke exhausters ar e shown i $\mathrm{n}$ Appendix 6, and the technical characteristics in table 1.

Table 1. Technical characteristics of VDN-17 draft machine

\begin{tabular}{|c|c|c|c|c|c|}
\hline $\begin{array}{c}\text { Types of } \\
\text { machines }\end{array}$ & $\begin{array}{c}\text { Power, } \\
\mathrm{kWt}\end{array}$ & $\begin{array}{c}\text { Rotation } \\
\text { frequency, } \\
\mathrm{min}^{-1}\end{array}$ & $\begin{array}{c}\text { Product } \\
\text { ivity, } \\
\mathrm{m}^{3} / \mathrm{h}\end{array}$ & $\begin{array}{c}\text { Total } \\
\text { pressure, } \\
\mathrm{Pa}\end{array}$ & $\begin{array}{c}\text { Weight } \\
, \mathrm{kg}\end{array}$ \\
\hline $\mathrm{VDN}-17$ & 160 & 980 & 73000 & 282 & 3100 \\
\hline
\end{tabular}

\subsection{Method and calculation of an active silencer made of basalt fiber}

One of the methods of collective protection is the use of mufflers, which are u sed to r educe aer odynamic noise. According to the principle of ope ration, n oise m ufflers are: act ive type (due to the sound-absorbing $m$ aterial), reactive type (due to the reflection of a part of the sound energy back to the source) and combined [15].

The $\mathrm{p}$ aper proposes t o u se a $\mathrm{n}$ act ive t ype muffler, which i s e ffective at medium an des pecially high frequencies. An act ive muffler i $\mathrm{nt}$ he form o fa rectangular c hannel will be located at the outlet of the VDN-17 fan along the perimeter of the pipeline. the fan is fastened to the unloading chamber in the form of a rectangular pipe with an internal width of $-850 \mathrm{~mm}$ and a length of $635 \mathrm{~mm}$. To prevent the a bsorbing material from blowing out, coverings with metal mesh, perforated material, etc. are used.

The muffler is a thin-walled rectangular parallelepiped with a length of $850 \mathrm{~mm}$, a width of 632 $\mathrm{mm}$ and a depth of $1100 \mathrm{~mm}$, the inner part of which is sheathed with a heat-resistant mesh with a wire thickness of $1.6 \mathrm{~mm}$ to prevent material blowing out.

The cal culation o $\mathrm{f} n$ oise $\mathrm{r}$ eduction ( acoustic efficiency) when using an a ctive silencer $f$ or a rectangular duct is carried out according to the following formula (1):

$$
\Delta L=1,1 \varphi(\alpha) \cdot P \cdot l / S
$$

where $\varphi(\alpha)$ - conditional sound absorption coefficient of the muffler 1 ining, de pending on the s ound a bsorption coefficient $\alpha$ of the used adsorbent (table 2);

1 a nd $\mathrm{P}$ - respectively $\mathrm{t}$ he 1 ength a nd $\mathrm{d}$ iameter of $\mathrm{t}$ he cross-section of the muffler channel, $\mathrm{m}$

$\mathrm{S}$ - channel cross-sectional area, $\mathrm{m}^{2}[16]$.

Table 2. Values of the conditional sound absorption coefficient of the muffler lining depending on the sound absorption coefficient $\alpha$ of the used absorbent

\begin{tabular}{|l|l|l|l|l|l|l|l|l|l|l|}
\hline$\alpha$ & 0,1 & 0,2 & 0,3 & 0,4 & 0,5 & 0,6 & 0,7 & 0,8 & 0,9 & 1 \\
\hline$\varphi(\alpha)$ & 0,1 & 0,2 & 0,35 & 0,5 & 0,65 & 0,8 & 1,2 & 1,6 & 2,0 & 4 \\
\hline
\end{tabular}

Using formula 1, we calculate the acoustic efficiency of an active muffler for VDN-17:

$$
\Delta L=1,1 \varphi(\alpha) \cdot 2(0,85+0,632) \cdot 1,1 / 0,85 \cdot 0,632
$$




$$
\Delta L=6,68 \varphi(\alpha)
$$

When $\mathrm{c}$ hoosing a s ound-absorbing $\mathrm{m}$ aterial $\mathrm{f}$ or an active muffler, $\mathrm{it}$ is necessary to take into acco unt properties s uch a s: flammability, hazardousness t o the health of workers, $s$ ervice 1 ife, et $\mathrm{c}$. $\mathrm{T}$ he $\mathrm{m}$ aximum operating t emperature of glass wool is $500^{\circ} \mathrm{C}, \mathrm{s}$ lag wool $-300^{\circ} \mathrm{C}, \mathrm{b}$ asalt fiber $-1000^{\circ} \mathrm{C}$. B ased o $\mathrm{n}$ practical data for the use of active mufflers, depending on th e o perating $\mathrm{c}$ onditions, a material was $\mathrm{c}$ hosen basalt wool. They were selected on the basis that gases with a $n$ e levated $t$ emperature of a bout $900^{\circ} \mathrm{C}$ pa ss through VDN-17.

During operation of the VDN-17 blower fan, intense noise is e mitted into the working space, the frequency characteristic of which is shown in table 3.

Table 3. Frequency response of noise from VDN-17

\begin{tabular}{|c|c|c|c|c|c|c|c|c|}
\hline \multirow[t]{2}{*}{ Index } & \multirow{2}{*}{$\begin{array}{l}\text { Measur } \\
\text { ement } \\
\text { area }\end{array}$} & \multicolumn{7}{|c|}{$\begin{array}{c}\text { Average geometric frequencies of octave } \\
\text { bands, } \mathrm{Hz}\end{array}$} \\
\hline & & 125 & 250 & \begin{tabular}{|l|l|}
500 \\
\end{tabular} & 1000 & 2000 & 4000 & 8000 \\
\hline $\begin{array}{l}\text { Noise } \\
\text { from }\end{array}$ & $\begin{array}{l}\text { Injectio } \\
\mathrm{n}\end{array}$ & 112 & 117 & 116 & 113 & 111 & 107 & 101 \\
\hline the & Suction & 108 & 113 & 112 & 109 & 107 & 103 & 97 \\
\hline $\begin{array}{c}\text { VDN } \\
-17 \\
\text { fan }\end{array}$ & $\begin{array}{l}\text { Around } \\
\text { the } \\
\text { body }\end{array}$ & 103 & 107 & 106 & 103 & 100 & 95 & 89 \\
\hline
\end{tabular}

Since the muffler is installed at the fan outlet, it i s necessary $\mathrm{t}$ o cal culate i $\mathrm{nt}$ wo zo nes: $\mathrm{d}$ ischarge a nd around the casing.

\section{Results}

The in itial d ata a nd $\mathrm{r}$ esults o $\mathrm{f} \mathrm{c}$ alculating $\mathrm{t}$ he effectiveness of measures for installing a silencer made of a semi-rigid " PP-80" b asalt s lab in acco rdance with GOST 9573-2012 with a sound absorber thickness of 30 $\mathrm{mm}$ in the injection zone are summarized in table 4.

Table 4. The results of calculating the effectiveness of measures to install a silencer made of basalt fiber in the injection zone

\begin{tabular}{|c|c|c|c|c|c|c|c|}
\hline \multirow{2}{*}{ Index } & \multicolumn{6}{|c|}{ Average geometric frequencies of octave } \\
\cline { 2 - 8 } & 125 & 250 & 500 & 1000 & 2000 & 4000 & 8000 \\
\hline $\begin{array}{c}\text { Sound Pressure } \\
\text { Level from the } \\
\begin{array}{c}\text { VDN-17 fan, } \\
\mathrm{dB}\end{array}\end{array}$ & 112 & 117 & 116 & 113 & 111 & 107 & 101 \\
\hline $\begin{array}{c}\text { Sound } \\
\text { absorption } \\
\text { coefficient } \alpha\end{array}$ & 0,08 & 0,3 & 0,64 & 0,89 & 0,95 & 0,81 & 0,73 \\
\hline $\begin{array}{c}\text { Conditional } \\
\text { sound } \\
\text { absorption } \\
\text { coefficient } \varphi(\alpha)\end{array}$ & 0,08 & 0,35 & 0,96 & 1,96 & 3 & 1,64 & 1,32 \\
\hline $\begin{array}{c}\text { Silencer } \\
\text { acoustic } \\
\text { efficiency, dB }\end{array}$ & 1 & 3 & 7 & 14 & 22 & 12 & 10 \\
\hline
\end{tabular}

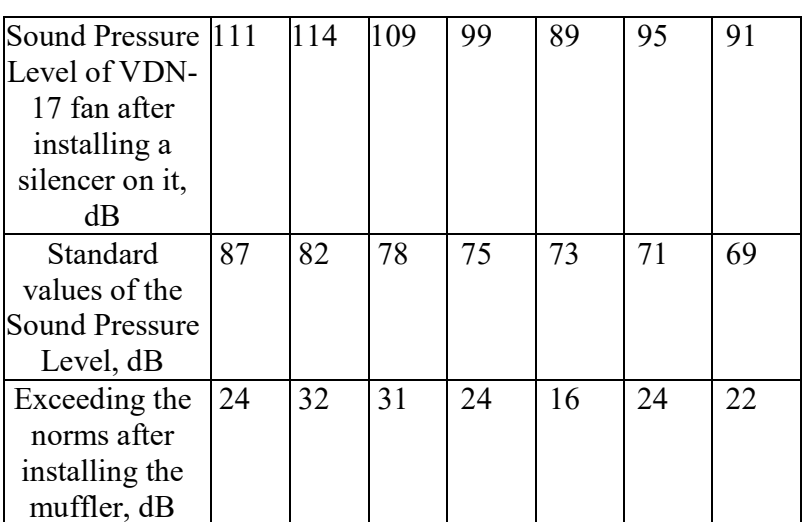

First, it is necessary to determine t he s ound absorption coefficient of the semi-rigid basalt slab PP-80 from the reference data. Using table 2, we calculate the value of the conditional s ound absorption c oefficient of the muffler 1 ining de pending on $t$ he $s$ ound a bsorption coefficient $\alpha$. Then we calculate the acoustic efficiency of $\mathrm{t}$ he muffler $\mathrm{d}$ epending on $\mathrm{t}$ he $\mathrm{g}$ eometric mean frequency using formula 3 . For example, at $125 \mathrm{~Hz}$, the acoustic efficiency of the muffler will be:

$$
\Delta L_{(125)}=6,68 \varphi(\alpha)_{(125)}=6,68 \cdot 0,8 \approx 1(\mathrm{~dB})
$$

where $\varphi(\alpha)_{(125)}$ - the $\mathrm{c}$ onditional s ound a bsorption coefficient of the muffler lining, which depends on the sound a bsorption c oefficient $\alpha$ of the s emi-rigid $b$ asalt PP-80 slab.

Thus, the s ound p ressure level of t he V DN-17 fan after in stalling a muffler on it in the discharge zo ne at $125 \mathrm{~Hz}$ :

$$
L_{p 2(125)}=\quad L_{p 1(125)^{-}} \quad \Delta L_{(125)}=112-1=111(\mathrm{~dB})
$$

where $L_{p 1(125)}$ - the sound pressure level of the VDN-17 fan $b$ efore i nstalling a muffler o $n$ it in th e $d$ ischarge zone.

Exceeding $t$ he standard $\mathrm{v}$ alues of sound pr essure levels after installing a muffler at $125 \mathrm{~Hz}$ :

$$
\Delta=L_{p 2(125)}-L_{\text {stand (125) }}=111-87=24(\mathrm{~dB})
$$

where $L_{\text {stand (125) }}$ - the standard va lue of the sound pressure level at $125 \mathrm{~Hz}$.

Similarcal culations for $\mathrm{t}$ he $\mathrm{g}$ eometric mean frequencies of the octave bands of 250, 500, 1000, 2000, 4000 and $8000 \mathrm{~Hz}$ were carried out in the excel program, the results are shown in Table 4. For the geometric mean frequencies of the oc tave ba nds of 31.5 a nd $63 \mathrm{H} \mathrm{z}$, calculations were not performed, since it was previously said that the active type muffler is effective at medium and high frequencies.

Based o $n$th e c alculation $r$ esults, we will $b$ uild th $e$ noise characteristic in the injection zone before and after the installation of the muffler (Fig.1). 


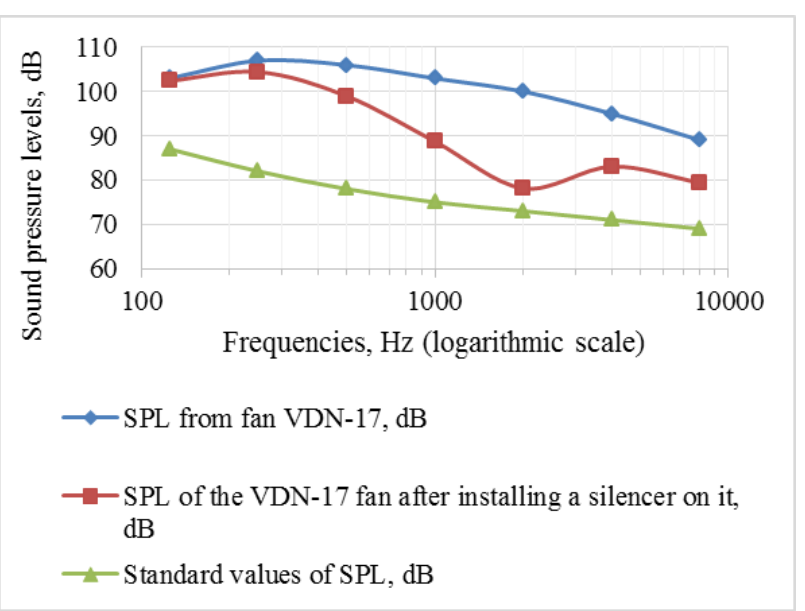

Fig. 1. Noise characteristics in the discharge zone before and after installation of the muffler

Similar cal culations were ca rried o ut $\mathrm{t} o$ as sess $t$ he effectiveness of measures to install a silencer made from a s emi-rigid " PP-80" b asalt s lab i $\mathrm{n}$ acco rdance with GOST 9573-2012 with a sound absorber thickness of 30 $\mathrm{mm}$ i $\mathrm{nt}$ he measurement $\mathrm{z}$ one a round $\mathrm{t}$ he $\mathrm{b}$ ody, $\mathrm{t}$ he results are shown in table 5 .

Table 5. Results of calculating the effectiveness of measures for installing a basalt fiber muffler in the measurement zone around the body

\begin{tabular}{|c|c|c|c|c|c|c|c|}
\hline \multirow{2}{*}{\begin{tabular}{c} 
Index \\
\cline { 2 - 8 }
\end{tabular}} & \multicolumn{7}{|c|}{$\begin{array}{c}\text { Average geometric frequencies of octave } \\
\text { bands, Hz }\end{array}$} \\
\cline { 2 - 8 } & 125 & 250 & 500 & 1000 & 2000 & 4000 & 8000 \\
\hline $\begin{array}{c}\text { Sound } \\
\text { Pressure Level } \\
\text { rom the VDN- } \\
17 \text { fan, dB }\end{array}$ & 103 & 107 & 106 & 103 & 100 & 95 & 89 \\
\hline $\begin{array}{c}\text { Sound } \\
\text { absorption } \\
\text { coefficient } \alpha\end{array}$ & 0,08 & 0,3 & 0,64 & 0,89 & 0,95 & 0,81 & 0,73 \\
\hline $\begin{array}{c}\text { Conditional } \\
\text { sound } \\
\text { absorption } \\
\text { coefficient } \\
\varphi(\alpha)\end{array}$ & 0,08 & 0,35 & 0,96 & 1,96 & 3 & 1,64 & 1,32 \\
\hline $\begin{array}{c}\text { Silencer } \\
\text { acoustic } \\
\text { efficiency, dB }\end{array}$ & 1 & 3 & 7 & 14 & 22 & 12 & 10 \\
\hline $\begin{array}{c}\text { Sound } \\
\text { Pressure Level } \\
\text { pf VDN-17 fan } \\
\text { after installing } \\
\text { silencer on it, } \\
\text { dB }\end{array}$ & 102 & 104 & 99 & 89 & 78 & 83 & 79 \\
\hline $\begin{array}{c}\text { Standard } \\
\text { values of the } \\
\text { pound Pressure } \\
\text { Level, dB }\end{array}$ & 87 & 82 & 78 & 75 & 73 & 71 & 69 \\
\hline $\begin{array}{c}\text { Exceeding the } \\
\text { norms after } \\
\text { installing the } \\
\text { muffler, dB }\end{array}$ & 24 & 32 & 31 & 24 & 16 & 24 & 22 \\
\hline
\end{tabular}

Based on the results of the calculation, we construct the noise characteristic in the measurement zone around the body before and after the installation of the muffler (Fig.2).

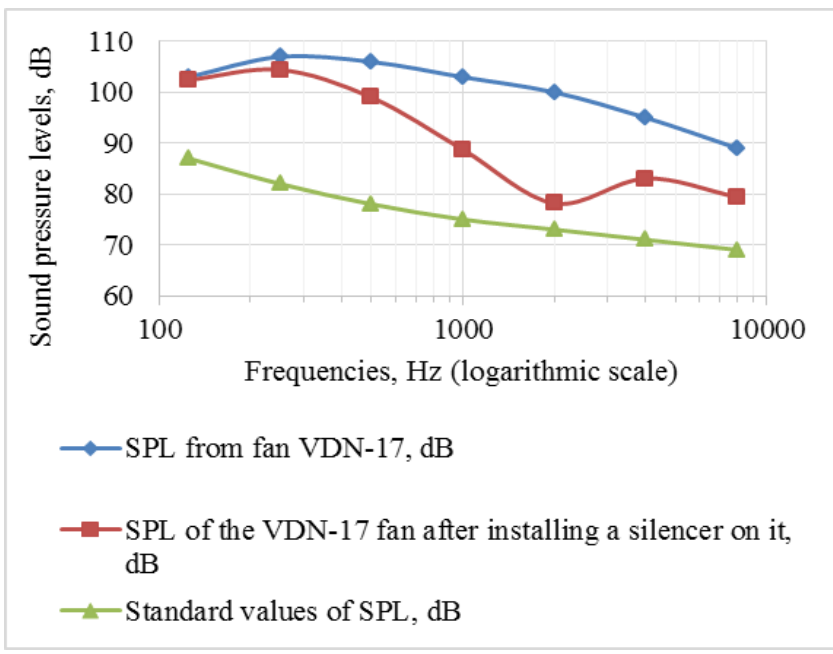

Fig. 2. Noise characteristic in the measuring area around the body before and after installing the muffler

As a result of the calculation, the acoustic efficiency of the muffler made of basalt semi-rigid slab PP-80 was determined a nd $t$ he $s$ ound $p$ ressure 1 evels $i n t$ he measurement zo nes were calculated: $i$ njection an $d$ around the body. B ased on Figures 2 and 3, it c an be seen that the muffler is most effective in the high frequency range.

The $\mathrm{m}$ uffler is made i $\mathrm{n} \mathrm{t}$ he $\mathrm{f}$ orm of a $\mathrm{r}$ ectangular channel and is installed at the outlet of the VDN-17 fan. In Figure 4, the number 8 de notes the VDN-17 fan, and the location of the muffler is indicated in green.

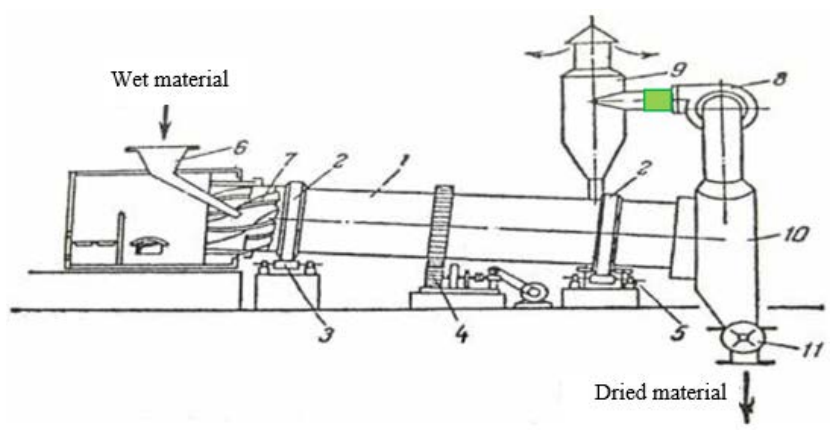

Fig. 3. Principle of operation of the drying drum (1 - drum; 2 bandages; 3 - support rollers; 4 - transfer; 5 - support rollers; 6 - feeder; 7 - blades; 8 - fan; 9 - cyclone; 10 - unloading chamber; 11 - unloading device)

\section{Discussion}

The study is dedicated to the development of measures to reduce the negative impact of industrial noise on the fitter-repairman to replace the filter cloth, during which the sources of noise generation were identified and methods of dealing with it were proposed.

During the work, on the basis of statistical data and scientific $r$ esearch, $i \mathrm{t}$ was revealed $t$ hat the $m$ ining industry is the most harmful and hazardous. W orld practice $\mathrm{s}$ hows that workers in this i ndustry belong to groups of increased risk of negative impact of industrial 
noise, which 1 eads $\mathrm{t}$ o $\mathrm{d}$ iseases o $\mathrm{ft}$ he hearing o rgans, nervous system and others $[17,18]$.

This work co nfirms the r elevance a nd $n$ ecessity of developing measures to $r$ educe $t$ he $n$ egative $i$ mpact of increased i ndustrial noise o $\mathrm{n}$ workers i $\mathrm{n} t$ he mining industry.

\section{References}

1. Federal s tate $\mathrm{s}$ tatistics s ervice. [Electronic s ource]. https://www.gks.ru/working_conditions ( accessed on 01.02.2020)

2. E. Kerns, E.A. Masterson, C.L. Themann, G.M. Calvert, American J ournal o f I ndustrial Medicine, 61(6), $477 \quad-491$ ( 2018) https://doi.org/10.1002/ajim.22833

3. L.K. K arimova, M.K. G ainullina, O.V. G rebeneva, E.R. Shay-Khlislamova, L.M. Mavrin, "O sostoyanii uslovij t ruda $r$ abotnic go rno-obogatitel'noj fabriki", 22 (2017) [in Russia]

4. T.V.G orokhova, E.M . E gorova, N .P. S etko, E.B. Beilina. "Osobennosti professional'noj zabolevaemosti rabotnikovg orno-obogatitel'nogo proizvodstva", 98 (2018) [in Russia]

5. Annual report of the Federal service for environmental, $\mathrm{t}$ echnological and $\mathrm{n}$ uclear supervision for 2018. [Electronic s ource]. https://zinref.ru/000_uchebniki/04600_raznie_7/215 _otchet_po_ekoloc_atomnome_nadzoru_2018/008.h tm (accessed on 01.02.2020).

6. E. S temn, S afety a nd $\mathrm{H}$ ealth at $\mathrm{W}$ ork, 10(2), 151 165 (2019) https://doi.org/10.1016/j.shaw.2018.09.001

7. A.G. K ochnev, V .Ya. B ershadskij, Mo lodezh i nauka, 8, 90 (2018) [in Russia]

8. L.K. K arimova an d o ther, $\mathrm{Z}$ dorov'e naseleniya $\mathrm{i}$ sreda obitaniya, 3(288), (2017) [in Russia]

9. E.A. $\mathrm{M}$ asterson, J .A. D eddens, C.L. T hemann, S. Bertke, G .M. C alvert, A merican J ournal o f Industrial Medicine, 58(4), 392-401 (2015).

10. A.P. S avel'ev, S .V.P 'yanzov, A.N. S kvorcov, Al'manah mirovoj na uki, 2-1, 14 2-143 (2015) [in Russia]

11. D.V. Parahin, Vystavka innovacij-2015 (osennyaya sessiya), 66-67 (2015) [in Russia]

12. A.S. Pirogov, M.I. S pel'nikova, Ugol', 6, 5 4-55 (2015).

13. N.V.R umyanceva, T .T. K averzneva, Uchebnometodicheskoe posobie: Opredelenie norm vydachi sredstv individual'noj zashchity metodicheskie rekomendacii po provedeniyu prakticheskih zanyatij po discipline «Ohrana truda» (Spb.: Iz d-vo Politekhn., un-ta, 23, 2019)

14. Tekhnicheskie ha rakteristiki i o pisanie. Tyagodut'evye mashiny VDN I DN ( VDN 6,3, DN 6,3, VDN 8, DN 8, VDN 9, DN 9, VDN 10, DN 10, VDN 11,2, DN 11,2, VDN 12 5, DN 12,5, VDN 13, DN 13, VDN 15, DN 15, VDN 17, DN 17, VDN 19,
DN 19, VDN 21, DN 21. GK "Novye tekhnologii" : Ventmash. [Electronic s ource]. h ttps://ventmash.ntrt.ru/images/manuals/1vdn.pdf ( accessed on 25.02.2020)

15. N.A. E vstigneeva, S .V. Ka rev, M ADI ( GTU), 44 (2007)

16. Proizvodstvennaya sanitariya i gigiena truda. Snizhenie aerodinamicheskogo shuma glushitelyami: Metodicheskie ukazaniya po vypolneniyu raschetno-graficheskoj raboty. (Nacional'nyj m ineral'no-syr'evoj uni versitet «Gornyj», Sost. V.V. Smirnyakova, Spb., 2012).

17. S.K. Karabalin and other, Mezhdunarodnyj zhurnal prikladnyh i fundamental'nyh issledovanij, 12, 71-75 (2019) [in Russia]

18. N.N. $\mathrm{M}$ azitova an $\mathrm{d} \mathrm{o}$ ther, $\mathrm{M}$ edicina $\mathrm{t}$ ruda $\mathrm{i}$ promyshlennaya e kologiya, 2, 4 8-53, ( 2017) [in Russia] 